\title{
MULTI TEMPORAL ASSESSMENT OF SHORELINE CHANGES USING \\ GEOINFORMATICS IN MUTHUPET LAGOON, TAMIL NADU, INDIA
}

\author{
ANNAIDASAN. K \& NARMADA. K
}

Research Scholars, Department of Geography, University of Madras, Chennai, Tamilnadu, India

\begin{abstract}
Coastal area which is mostly defined as the shoreline is the physical interface of land and water. This physical interface is very much dynamic in nature due to the interference of the human population as they provide economic and social security to the coastal habitations. Tamil Nadu, which occupies most of the coastal areas in. $e$ almost 1000 kms faces lots of threats and disturbances due to natural and anthropogenic interventions. Rapid urbanization, industrialization, sand and coral mining are some of the intervening agents that contribute to coastal degradation. Any change in the coastal environs causes a great impact on the economic and social development. The natural and anthropogenic activities play a major role in triggering erosion and accretion of the coastal ecosystem. In the current study the shoreline change detection was carried out using the Digital Shoreline Analysis System (DSAS). Linear Regression (LRR) and End Point Rate (EPR) techniques were used to study the rate of shoreline change. The ratio between the distance of shoreline change and the time between the earliest and latest measurements at each transect was found to give the End Point Rate (EPR). From the result, it was found that the $529^{\text {th }}$ transect showed a drastic change of more than $800 m$ change which is the highest change recorded. $430^{\text {th }}$ transect and $826^{\text {th }}$ transect also showed a change in shoreline of more than $700 \mathrm{~m}$. This is found to be a moderate change.

KEYWORDS: Shoreline Change, DSAS, Endpoint Rate, Geoinformatics \& Satellite Images
\end{abstract}

Received: Jul 28, 2017; Accepted: Aug 18, 2017; Published: Nov 14, 2017; Paper Id.: IJEEFUSDEC20171

\section{INTRODUCTION}

The interface between the land and the sea is called as the shoreline. The coastal ecosystem is a dynamic environment where there is a constant threat by various natural and anthropogenic forces. The coastal ecosystem is a fragile ecosystem which is highly vulnerable to different threats that are imposed on this environment. Various natural factors that affect the shoreline changes include waves, currents, tides and winds. All the factors affect even the geomorphological characteristics of the shore. Anthropogenic forcing that triggers coastal erosion includes building of artificial structures, mining of beach sand, offshore dredging or building of dams or rivers. These changes in the shorelines may be a long term change to a short term change. While the effects of waves, ue tides and winds are primary natural factors that influence the coastal erosion, the other aspects eroding the coastline include the sand sources and sinks, changes in relative sea level, geomorphological characteristics of the shore etc. (Addo 2008) Integrated Coastal Zone Management (ICZM) is a major concern now a days due to the dynamic nature of the shoreline and due to the detrimental effects of the change. The change in the shorelines can be one of the major environmental indicators affecting the economic and social set up of the coastal ecosystem. In India that has a huge coastal line the change can create a major impact on the costal population and the natural environment. The displacement of the shore towards the land over a period of time due to various reasons is called as coastal 
erosion. Various natural forces like the waves, winds and tides and even anthropogenic forces create a loss of sub aerial land mass into the sea.

\section{STUDY AREA}

The district of Nagapattinam, Thiruvarur and Thanjavur, in the southern most areas harbours a mangrove wetland of Vedaranyam called as Muthupet Mangrove. The mangroves cover an area $13.32 \mathrm{~km}^{2}$ in the year 2015 (April) and was acquired from the satellite data Landsat ETM image. The volume was found to be $9.6 \times 106 \mathrm{~m}^{3}$ (as estimated for Febraury - March 2015). It is also called as Vedaranyam Marsh as it is a part of large coastal wetland. This area has a gentle slope towards the Palk Strait of Bay of Bengal. The distributaries of Cauvery viz., Paminiyar, Koraiyar, Kandaparichanar, Kilaithangiyar and Marakkakoraiyar discharge their water into the wetlands and form a large lagoon before reaching the sea. The wetland harbors a lot of tidal streams, channels and small bays. The mangroves are found in the borders of the wetlands primarily in the western part of the wetland. Intensive fishing is carried out in this area. Northeast monsoon is the most favorable season as the major inflow happens in this region through various drainage arteries that serve the agricultural areas, mangrove swamps and the aquaculture ponds. The discharge into these mangroves is not much significant in the month of February to September. The soil here is of dual nature where it is clayey silt in the lagoon and silty clay in the area towards the land due to the fresh silt deposits.

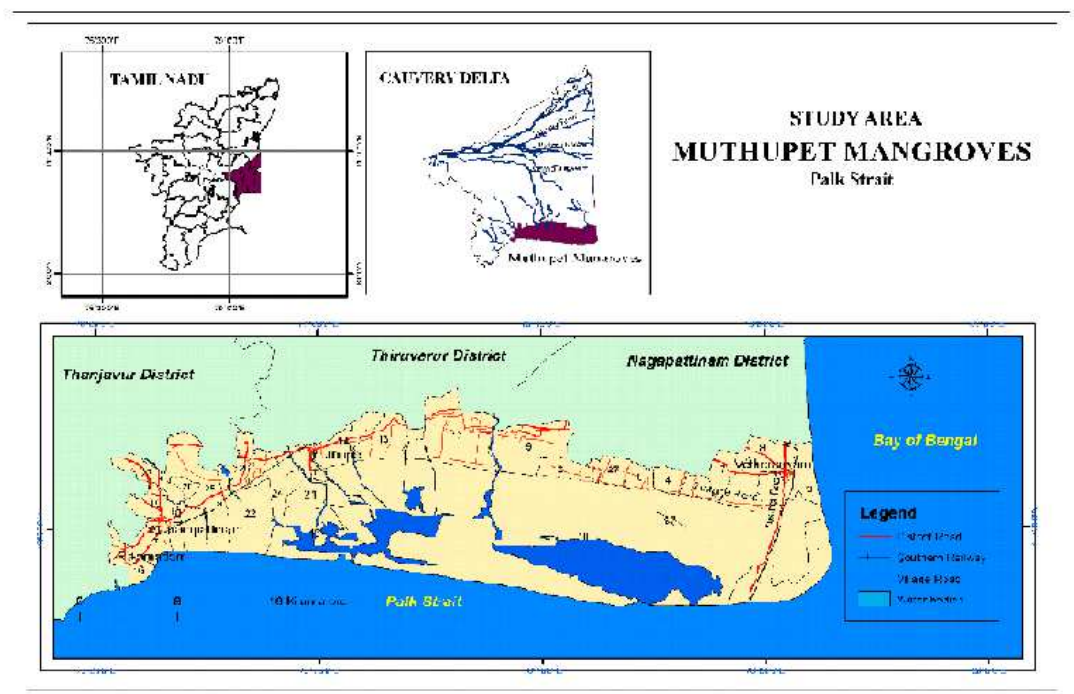

Figure 1: Study Area, Muthupet Mangroves

Table 1: Data Sources

\begin{tabular}{|c|l|c|}
\hline S. No & \multicolumn{1}{|c|}{ Data and Sensor } & Spatial Resolution \\
\hline 1 & Landsat MSS 1985 & \\
\hline 2 & Landsat TM 1995 & 30 \\
\hline 3 & Landsat ETM 2005 & 30 \\
\hline 4 & Landsat 8 OLI 2015 & 30 \\
\hline
\end{tabular}

\section{METHODOLOGY}

Four different types of satellite sensors were used, such as MSS, TM, ETM, and OLI which were acquired from USGS Earth Explorer. The Shoreline Changes were analyzed using Digital Shoreline Analysis System (DSAS). Satellite 
images for different periods were taken for the study. The shorelines of different periods were created and the shorelines were merged. The shorelines created to form the baseline data for the study. From the shorelines that were created from the images the transect line was prepared. The $50 \mathrm{M}$ buffer line was taken to understand the extent of the shoreline change over the stretch. From the transects, the statistical analysis was carried out. The maps that were created from the satellite images were exported. The accretions and the erosion rates of the shorelines were calculated. The output derived from the analysis were transferred to an excel sheet to calculate the total area covered by the shoreline in the form of a bar diagram. The final results were interpreted in the form of maps.

\section{RESULTS AND DISCUSSIONS}

Accretion and erosion are two opposite processes with each other, accretion increases the area of agricultural, forest and fishing land, but when the sedimentation process occurs, it affects the waterway transportation activities. While erosion causes the loss of land, demolishes constructed building up areas, it has been threatening human, flora and fauna habitat. The present research results show that the erosion had taken place on a large scale. The coastline in this region has been detected by using the Satellite Data. Moreover the mangrove forest have been degraded for converting to the fish and shrimp ponds and other build up process These are the major causes of coastal erosion in this area.

Digital Shoreline Analysis System (DSAS) has been used to detect the changes in the shorelines in the Muthupet region. From the shorelines that were extracted for different years, transects were prepared. This was done by dividing the distance between the earliest to the latest measurement randomly for every 500 meters. From the derived result the Shoreline Change envelope and the end point rate were calculated to estimate the change, The shoreline change envelope was calculating the distance between the shorelines that farthest and closest to the baseline for a given transect. The end point rate was calculated by dividing the distance between earliest to the latest measurement. These results are interpreted in the form of a graph. The transects 529 shows high rate of change according the output got from shoreline change envelope graph. The transects 430 and 826 also shows high rate of change. From the End Point Rate (EPR) calculations the maximum rate of change was found in the transect 430.

\section{BASELINE CREATIONS}

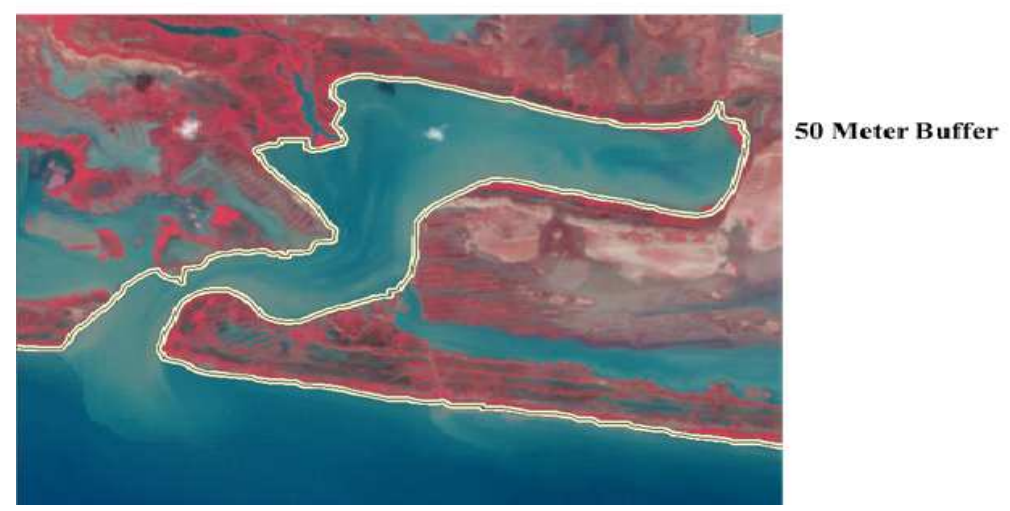

Figure 2: Delineate Shoreline from the Remotely Sensed Data with Different Sensor 


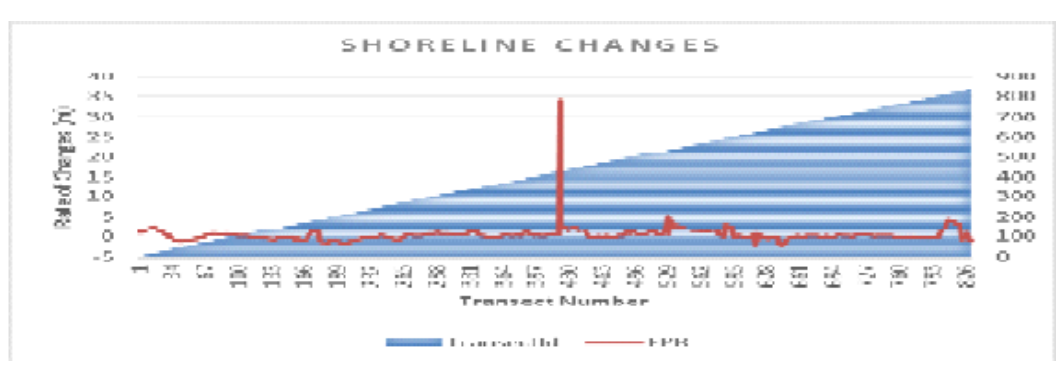

Figure 3: Endpoint Rate in each Transect

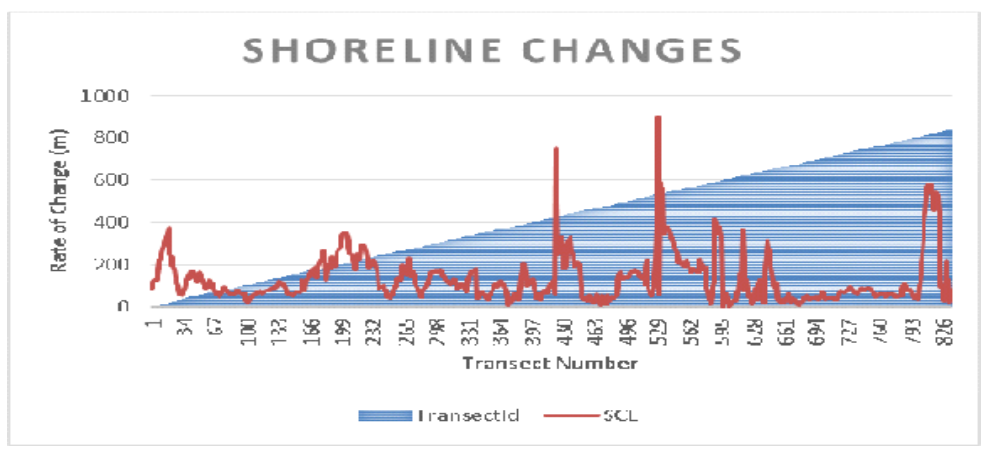

Figure 4: Shoreline Change Envelope in each Transect

The end point rate (EPR) is computed by dividing the distance of shoreline movement by the time gone between the first and last measurements (i.e the shoreline from the oldest and the latest image). The easy computation of the analytical process and the minimum requirement of the shoreline data are the main advantages of this EPR technique. The EPR shows that rate of changes of EPR which given by DSAS tool.

\section{CONCLUSIONS}

This study demonstrates that the integration of GIS technology is very much useful for long term shoreline change studies with reasonable accuracy. Further, this can be carried out using high resolution images, so that shorelines can be demarcated more accurately. The major forces that are the cause for the modification of the configuration of the coastal zone are both natural (littoral drift, tidal action, near shore bathymetry) and man-made (construction of seawalls, groins or breakwaters). The trigger both erosion and accretion of the coastal zone. The authorities for conservation of the coastal ecosystem have to facilitate suitable management plans and regulation of coastal zones. The result of shoreline change map will be more useful for coastal engineers and coastal zone management authorities to facilitate suitable management plans and regulation of coastal zones.

\section{REFERENCES}

1. Alesheikh, A. A., Ghorbanali, A., and Nouri, N., (2007), Coastline change detection using remote sensing”, International Journal of Environment Science and Technology, 4, pp 61-66.

2. Carter, R.W.G., and Woodroffe, C.D, (1994), Coastal evolution: Late quaternary shoreline morphodynamics. Cambridge: Cambridge University Press, 517.

3. Charatkar, S.L., Mitra, D., Biradar, R.S., and Radhakrishnan, K.V, (2004), A study of erosion and accretion along Gulf of Khambat, Gujarat coast using remote sensing and GIS. AFITA/WCCA, Joint Congress on Agriculture, Bangkok, Thailand, pp $574-589$. 
4. Chorly, R.J., Schemm, S.A., and Sngden, D.E., (1984) Geomorphology. Methuen, London, p 605.

5. Cowell, P.J. and B.G. Thorn., (1994). Morphodynamics of coastal evolution. In: Carter, R.W.G. and Woodroffe, C.D., (eds.), Coastal Evolution. Cambridge: Cambridge University Press, pp 33-86.

6. Dey, S., Dutta, S., and Adak, S.B., (2002), Holocene sea level change of West Bengal Coast. Indian Geogr. J 77(1), pp 7-20.

7. Dolan, R., Hayden, B.P., May, P., and May, S. K., (1980), The reliability of shoreline change measurements from aerial photographs. Shore and Beach, 48(4), pp 22-29. 
